\title{
Comparison of tumor-targeting properties of directly and indirectly radioiodinated designed ankyrin repeat protein (DARPin) G3 variants for molecular imaging of HER2
}

\author{
ANZHELIKA VOROBYEVA ${ }^{1}$, ALEXEY SCHULGA ${ }^{2}$, ELENA KONOVALOVA ${ }^{2}$, REZAN GÜLER ${ }^{3}$, \\ BOGDAN MITRAN ${ }^{4}$, JAVAD GAROUSI $^{1}$, SARA RINNE $^{4}$, JOHN LÖFBLOM $^{3}$, ANNA ORLOVA $^{4,5}$, \\ SERGEY DEYEV ${ }^{2,6,7}$ and VLADIMIR TOLMACHEV ${ }^{1}$
}

\author{
${ }^{1}$ Department of Immunology, Genetics and Pathology, Uppsala University, SE 75185 Uppsala, Sweden; \\ ${ }^{2}$ Molecular Immunology Laboratory, Shemyakin and Ovchinnikov Institute of Bioorganic Chemistry, \\ Russian Academy of Sciences, 117997 Moscow, Russia; ${ }^{3}$ Department of Protein Science, \\ School of Engineering Sciences in Chemistry, Biotechnology and Health, KTH Royal Institute of Technology, \\ SE 10691 Stockholm; ${ }^{4}$ Department of Medicinal Chemistry; ${ }^{5}$ Science for Life Laboratory, Uppsala University, \\ SE 75183 Uppsala, Sweden; ${ }^{6}$ Bio-Nanophotonic Lab, Institute of Engineering Physics for Biomedicine (PhysBio), \\ National Research Nuclear University 'MEPhI', 115409 Moscow; ${ }^{7}$ Nuclear Medicine Department, \\ Cancer Research Institute, Tomsk National Research Medical Center Russian Academy of Sciences, 634050 Tomsk, Russia
}

Received September 27, 2018; Accepted January 25, 2019

DOI: $10.3892 /$ ijo.2019.4712

\begin{abstract}
Evaluation of human epidermal growth factor receptor 2 (HER2) expression levels in breast and gastroesophageal cancer is used for the stratification of patients forHER2-targeting therapies. The use of radionuclide molecular imaging may facilitate such evaluation in a non-invasive way. Designed ankyrin repeat proteins (DARPins) are engineered scaffold proteins with high potential as probes for radionuclide molecular imaging. DARPin G3 binds with high affinity to HER2 and may be used to visualize this important therapeutic target. Studies on other engineered scaffold proteins have demonstrated that selection of the optimal labeling approach improves the sensitivity and specificity of radionuclide imaging. The present study compared two methods of labeling G3, direct and indirect radioiodination, to select an approach providing the best imaging contrast. $\mathrm{G} 3-\mathrm{H}_{6}$ was labeled with iodine-124, iodine-125 and iodine-131 using
\end{abstract}

Correspondence to: Dr Anzhelika Vorobyeva, Department of Immunology, Genetics and Pathology, Uppsala University, Dag Hammarskjölds v 20, SE 75185 Uppsala, Sweden

E-mail: anzhelika.vorobyeva@igp.uu.se

Abbreviations: DARPin, designed ankyrin repeat protein; HER2, human epidermal growth factor receptor 2; HPEM, [(4-hydroxyphenyl) ethyl] maleimide; PET, positron emission tomography; CT, computed tomography; SPECT, single photon emission computed tomography; HPLC, high performance liquid chromatography

Key words: DARPin, HER2, imaging, radionuclide, iodine, radioiodination a direct method. A novel construct bearing a C-terminal cysteine, G3-GGGC, was site-specifically labeled using [25I]I-iodo-[(4-hydroxyphenyl)ethyl]maleimide (HPEM). The two radiolabeled G3 variants preserved binding specificity and high affinity to HER2-expressing cells. The specificity of tumor targeting in vivo was demonstrated. Biodistribution comparison of $\left[{ }^{131} \mathrm{I}\right] \mathrm{I}-\mathrm{G} 3-\mathrm{H}_{6}$ and $\left[{ }^{125} \mathrm{I}\right] \mathrm{I}-\mathrm{HPEM}-\mathrm{G} 3-\mathrm{GGGC}$ in mice, bearing HER2-expressing SKOV3 xenografts, demonstrated an appreciable contribution of hepatobiliary excretion to the clearance of $\left[{ }^{125} \mathrm{I}\right] \mathrm{I}-\mathrm{HPEM}-\mathrm{G} 3-\mathrm{GGGC}$ and a decreased tumor uptake compared to $\left[{ }^{131} \mathrm{I}\right] \mathrm{I}-\mathrm{G} 3-\mathrm{H}_{6}$. The direct label provided higher tumor-to-blood and tumor-to-organ ratios compared with the indirect label at $4 \mathrm{~h}$ post-injection. The feasibility of high contrast PET/CT imaging of HER2 expression in SKOV3 xenografts in mice using $\left[{ }^{124} \mathrm{I}\right] \mathrm{I}-\mathrm{G} 3-\mathrm{H}_{6}$ was demonstrated. In conclusion, direct radioiodination is the preferable approach for labeling DARPin G3 with iodine-123 and iodine-124 for clinical single photon emission computed tomography and positron emission tomography imaging.

\section{Introduction}

Molecular imaging of cancer-associated targets facilitates the diagnosis and stratification of patients for targeted treatment. In patients with breast cancer, overexpression of human epidermal growth factor receptor 2 (HER2) is a predictor of poor prognosis. HER 2 is an established therapeutic target in breast and gastroesophageal cancer $(1,2)$. Anti-HER2 therapeutic agents including the monoclonal antibody trastuzumab, trastuzumab-DM1 conjugates and the tyrosine kinase inhibitor lapatinib, have been demonstrated to significantly improve the survival of patients with breast and gastric cancer (1,3-5). However, only $\sim 20 \%$ of breast tumors have a sufficiently high 
level of HER2 for successful targeting (6). Therefore, accurate determination of the HER2 level in tumors is critical for making a decision about targeted therapy.

The current clinical method of evaluating HER 2 expression is biopsy sampling followed by immunohistochemistry and/or fluorescence in situ hybridization analysis (7). The principal disadvantage of biopsy-based diagnostics is the morbidity associated with the invasiveness of the procedure, which limits the number of samples taken; the expression in only a few metastases may thus be determined. Heterogeneity of HER2 expression and discrepancies in expression between the primary tumor and metastases make the accurate determination of HER2 expression in disseminated disease challenging (8-10).

Molecular imaging is a non-invasive method for the global detection of HER2 expression that may overcome the limitations of current procedures. Therapeutic antibodies radiolabeled with $\gamma$ - or positron-emitters may be repurposed for single photon emission computed tomography (SPECT) or positron emission tomography (PET) imaging with lower translational costs, since the safety and toxicity profiles of approved antibodies are well defined. However, the major problem with using antibodies to image tumors is the low contrast, due to their slow accumulation and long half-lives. Small engineered scaffold proteins (ESPs) are promising targeting probes for molecular imaging due to their potentially high affinities for targets and rapid clearance from the blood and normal tissues (11). Various ESPs, including affibody molecules (12), ABD-derived affinity proteins (ADAPTs) (13), fibronectin domains (14), knottins (15) and anticalins (16), have demonstrated high sensitivity of radionuclide imaging in preclinical studies. Affibody molecules labeled with gallium-68 have been successfully used for whole-body quantification of HER2 expression using PET/computed tomography (CT) imaging in the clinic (17).

Designed ankyrin repeat proteins (DARPins) are small ESPs selected for their high-affinity binding to numerous cancer-associated targets. However, the number of studies concerning their potential for imaging is limited. DARPins are built of tightly packed repeat modules of 33 amino acids (18). Their generally high stability, solubility and aggregation resistance have made them important tools in a number of research applications. Clinical trials assessing the efficacy and safety of an anti-VEGF DARPin in patients with macular degeneration have reported promising results (19). DARPin G3 $(14.5 \mathrm{kDa})$ is a variant that binds to domain IV of HER2 with picomolar affinity (20). Biparatopic G3-based DARPins have demonstrated efficient growth suppression of HER2-expressing xenografts and lack of toxicity at high doses (up to $60 \mathrm{mg} / \mathrm{kg}$ ) in preclinical studies $(21,22)$, and are currently being evaluated in a clinical trial (23). DARPin G3 labeled with indium-111, technetium-99m and radioiodine has demonstrated efficient tumor targeting with a favorable biodistribution profile $(20,24)$.

High-contrast molecular imaging is achieved when the uptake of an imaging probe in tumors is several folds higher compared with the uptake in healthy tissues. Our previous study indicated that the internalization of anti-HER2 DARPins in tumors is relatively slow; however, internalization in excretory organs (the liver and kidneys) is rapid (25). A comparison of residualizing and non-residualizing labels for DARPins demonstrated that the use of non-residualizing labels (labels producing lipophilic catabolites that leak from cells following internalization and lysosomal proteolysis) resulted in the rapid removal of radiocatabolites from the liver and kidneys, providing decreased activity in these organs and increased contrast.

Radioisotopes of iodine provide versatile non-residualizing labels for preclinical studies (iodine-125) and clinical SPECT (iodine-123) and PET (iodine-124) imaging. Radioiodination of proteins may be performed using a number of labeling strategies. Direct labeling using chloramine-T is a robust and straightforward method. However, electrophilic oxidative radioiodination of tyrosines provides random attachment of the radionuclide to a protein. Modification of tyrosines in the binding site may negatively influence the affinity. For example, in the case of anti-HER 2 affibody molecules, this method was not applicable as they lost binding specificity following direct radioiodination (26). Indirect labeling using a bifunctional linker facilitates site-specific attachment of the label with control over the position and number of labels per protein. The choice of a label and labeling method may influence the biodistribution of the labeled protein and the re-distribution of radiocatabolites. Indirect labeling has been reported to reduce the accumulation of radiocatabolites in organs with expression of sodium-iodide symporters, including the salivary glands, thyroid and stomach $(27,28)$. Therefore, the selection of an optimal strategy may lead to a substantial improvement in imaging contrast.

The goal of the present study was to select a labeling method for radioiodination of DARPin G3, providing the best imaging contrast. Direct and indirect radioiodination methods were compared. Direct labeling of G3 has been previously reported by Goldstein et al (24). For site-specific labeling, a cysteine was introduced through a triglycine spacer-GGGC at the $\mathrm{C}$ terminus of G3. As the DARPin scaffold does not contain cysteines, the thiol group of the engineered cysteine was used for site-specific maleimide-thiol coupling. A maleimide derivative of tyramine, [(4-hydroxyphenyl)ethyl] maleimide (HPEM), was used as a bifunctional linker in this study.

\section{Materials and methods}

General materials and instruments. The molecular weight of the DARPins was measured by liquid chromatography-electrospray ionization-mass spectrometry on a 6520 Accurate Q-TOF LC/MS (Agilent Technologies, Inc., Santa Clara, CA, USA) with a mass range of $250-2,500 \mathrm{~m} / \mathrm{z}$ and positive ionization mode. The method was divided into three segments: 0-3 min, 3-7 min and 7-10 min. The parameters were set as follows: Nitrogen gas temperature, $350^{\circ} \mathrm{C}$ for all segments; nebulizer pressure, $15 \mathrm{psi}$, $25 \mathrm{psig}$ and $40 \mathrm{psig}$; and drying gas flow rate, $5 \mathrm{l} / \mathrm{min}, 5 \mathrm{l} / \mathrm{min}$ and $9 \mathrm{l} / \mathrm{min}$. Iodine radioisotopes $\left[{ }^{124} \mathrm{I}\right] \mathrm{NaI},\left[{ }^{125} \mathrm{I}\right] \mathrm{NaI}$ and $\left[{ }^{131} \mathrm{I}\right]$ NaI were purchased from PerkinElmer Sverige AB (Upplands Väsby, Sweden). Instant thin-layer chromatography (iTLC) analysis was performed using iTLC silica gel strips (Varian Medical Systems, Palo Alto, CA, USA). The activity distribution was measured using a Cyclone storage phosphor system and analyzed using OptiQuant image analysis software (version 2.5) (both from PerkinElmer, Waltham, MA, USA). Size-exclusion 
chromatography was performed using NAP-5 columns (GE Healthcare, Chicago, IL, USA). Radio-high performance liquid chromatography (HPLC) analysis was performed using Hitachi Chromaster HPLC systems with radioactivity detector and Vydac RP C18 column (300 ̊; 3x150 mm; 5- $\mu \mathrm{m})$ at room temperature $\left(20^{\circ} \mathrm{C}\right)$. The sample quantity used for analysis was $5 \mu \mathrm{l}$. Solvent A was $0.1 \%$ trifluoroacetic acid (TFA) in $\mathrm{H}_{2} \mathrm{O}$; solvent $\mathrm{B}$ was $0.1 \%$ TFA in acetonitrile. The flow rate was $1 \mathrm{ml} / \mathrm{min}$, with a $5 \% \mathrm{~B}$ to $80 \% \mathrm{~B}$ gradient over $20 \mathrm{~min}$. Activity was measured using an automated $\gamma$-spectrometer with an NaI(TI) detector (1480 Wizard; PerkinElmer Wallac Oy, Turku, Finland). SKOV3, BT474, DU145 and A431 cells were purchased from the American Type Culture Collection and were cultured in RPMI-1640 medium (Biochrom GmbH, Berlin, Germany) supplemented with $10 \%$ fetal bovine serum (Sigma-Aldrich; Merck KGaA, Darmstadt, Germany), 2 mM L-glutamine, $100 \mathrm{IU} / \mathrm{ml}$ penicillin and $100 \mu \mathrm{g} / \mathrm{ml}$ streptomycin in a humidified incubator with $5 \% \mathrm{CO}_{2}$ at $37^{\circ} \mathrm{C}$, unless stated otherwise.

Protein production. DARPins G3- $\mathrm{H}_{6}$ and G3-GGGC were produced in Escherichia coli strain BL21(DE3) (Novagen; EMD Millipore, Billerica, MA, USA). The genes for DARPin $\mathrm{G} 3-\mathrm{H}_{6}$ and $\mathrm{G} 3-\mathrm{GGGC}$ were deduced from a DARPin G3 amino acid sequence deposited in the Protein Data Bank (PDB) database (https://www.rcsb.org; PDB accession no. 2JAB), taking into account the codon usage in highly expressed $E$. coli genes. The amino acid sequence encoded by the DARPin $\mathrm{G} 3-\mathrm{H}_{6}$ gene was as follows: MDLGKKLLEAARAGQDDEVRILMANGA DVNAKDEYGLTPLYLATAHGHLEIVEVLLKNGADVNA VDAIGFTPLHLAAFIGHLEIAEVLLKHGADVNAQDKFG KTAFDISIGNGNEDLAEILQKLNGSHHHHHH. The gene was cloned into the plasmid vector pET39b (Novagen; EMD Millipore) between restriction sites NdeI and HindIII. The amino acid sequence of G3 containing a three glycine spacer and a cysteine at the C-terminus (G3-GGGC) was as follows: DLGKKLLEAARAGQDDEVRILMANGADVNAKDEYGL TPLYLATAHGHLEIVEVLLKNGADVNAVDAIGFTPLHL AAFIGHLEIAEVLLKHGADVNAQDKFGKTAFDISIGNG NEDLAEILQKLNGGGGC. The DARPin G3-GGGC gene was fused to the 3'-terminus of the small ubiquitin related modifier (SUMO) gene (29) by overlapping polymerase chain reaction (30). The procedure was performed in two steps. First, the DNA fragments containing the SUMO and DARPin G3-GGGC genes were amplified via PCR using primers T7dir (5'-GCGAAATTAATACGACTCACTATAGGG-3') and Sur (5'-GCCACCAATCTGCTCAC-3') for the SUMO gene and primers SG (5'-GTGAGCAGATTGGTGGCGACCTGGGCA AGAAACTG-3') and T7rev (5'-GGGTTATGCTAGTTATTG CTCAGC-3') for the DARPin G3-GGGC gene. The primers Sur and SG contained the complementary sequences (underlined). Second, the fragments were fused by PCR using the primer pair T7dir and T7rev. PCR reactions were performed with the thermostable polymerase Tersus (Evrogen JSC, Moscow, Russia), following the conditions recommended by the supplier. The junction between two genes encoded the following amino acid sequence (SUMO)-QIGG †DLGKK-(DARPin G3-GGGC). The 5'-terminus of the SUMO gene was extended with the coding sequence GHHHHHHGS. The hybrid SUMO-DARPin G3-GGGC gene was cloned into the pET39b plasmid vector between restriction sites NdeI and HindIII. Briefly, E. coli was grown in autoinduction ZYM-5052 medium prepared according to Studier (31) containing $100 \mu \mathrm{g} / \mathrm{ml}$ kanamycin at $25^{\circ} \mathrm{C}$. The cells were harvested by centrifugation at $10,000 \mathrm{x} \mathrm{g}$ at $4^{\circ} \mathrm{C}$ for $20 \mathrm{~min}$, and resuspended in lysis buffer [200 mM Tris-HCl, 500 mM sucrose, 1 mM EDTA (pH 8.0), $1 \mathrm{mM}$ PMSF and $60 \mu \mathrm{g} / \mathrm{ml}$ lysozyme]. The suspension was diluted 2-fold with distilled water and incubated at room temperature for $30 \mathrm{~min}$. Cells were broken on ice using a Vibra Cell ultrasonic liquid processor VCX130 (Sonics \& Materials, Inc., Newtown, CT, USA). The cellular debris were pelleted at $70,000 \mathrm{x} \mathrm{g}$ at $4^{\circ} \mathrm{C}$ for $30 \mathrm{~min}$. After addition of imidazole $(30 \mathrm{mM})$ and $\mathrm{NaCl}(500 \mathrm{mM})$, the supernatant was filtered through a $0.22 \mu \mathrm{m}$ membrane and applied onto a HisTrap HP $1 \mathrm{ml}$ column (GE Healthcare) equilibrated with $20 \mathrm{mM} \mathrm{NaPi}$ (pH 7.5), $500 \mathrm{mM} \mathrm{NaCl}$ and $30 \mathrm{mM}$ imidazole. The bound proteins were eluted with a linear $30-500 \mathrm{mM}$ imidazole gradient. The DARPin G3- $\mathrm{H}_{6}$ solution, diluted 5-fold with 25 mM Tris-Cl (pH 8.0), was loaded onto a MonoQ 10/100 GL column (GE Healthcare) equilibrated with the same buffer. The bound proteins were eluted with a linear 0-1 $\mathrm{M} \mathrm{NaCl}$ gradient. The fractions were analyzed by $15 \%$ reducing SDS-PAGE. Protein concentration was determined by UV spectroscopy using $\varepsilon_{280}=2,560 \mathrm{M}^{-1} \mathrm{~cm}^{-1}$.

The in-house-produced SUMO hydrolase (ULP1) (29) was added to the SUMO-G3-GGGC solution at a molar ratio of 1:100 (enzyme: substrate). The solution was incubated at $6^{\circ} \mathrm{C}$ overnight, diluted 5-fold with $20 \mathrm{mM} \mathrm{NaPi}$ (pH 7.5) and applied to a HisTrap HP $1 \mathrm{ml}$ column equilibrated with the same buffer. The flow-through eluate was collected, 2-mercaptoethanol was added to a final concentration of $50 \mathrm{mM}$ and the protein sample was loaded onto Mono Q 10/100 GL column equilibrated with $20 \mathrm{mM} \mathrm{NaPi}, 50 \mathrm{mM}$ 2-mercaptoethanol ( $\mathrm{pH}$ 7.5). The bound protein was eluted with a linear $0-1 \mathrm{M} \mathrm{NaCl}$ gradient. The fractions containing DARPin G3-GGGC were pooled and concentrated with an Amicon Ultra-15 centrifugal filter (Merck KGaA). The centrifugation was performed at $4,000 \mathrm{x} \mathrm{g}$ at $4^{\circ} \mathrm{C}$ for $20 \mathrm{~min}$. The resultant protein solution was sterilized by filtration through a $0.22 \mu \mathrm{m}$ membrane. Protein concentration was determined by UV spectroscopy using $\varepsilon_{280}=2,980 \mathrm{M}^{-1} \mathrm{~cm}^{-1}$.

Radiolabeling and stability. Direct radioiodination of $\mathrm{G} 3-\mathrm{H}_{6}$ with iodine-125, iodine-131 or iodine-124 using the chloramine-T method was performed, as described previously for DARPin 9_29 (25).

Site-specific labeling of G3-GGGC with iodine-125 was performed in three steps using maleimide-cysteine conjugation. In the first step, reduction of G3-GGGC by dithiothreitol (DTT) was performed to ensure the availability of cysteine for conjugation. To a solution of G3-GGGC (550 $\mu \mathrm{g}$; $41 \mathrm{nmol})$ in degassed PBS (45 $\mu \mathrm{l}), 1,000$-fold molar excess of DTT (4.1 $\mu \mathrm{l}$ of $1 \mathrm{M}$ solution; $632 \mu \mathrm{g}$; $4.1 \mathrm{nmol}$ ) was added. Following incubation at $40^{\circ} \mathrm{C}$ for $1 \mathrm{~h}, \mathrm{G} 3-\mathrm{GGGC}$ was purified using a NAP-5 size-exclusion column, pre-equilibrated with degassed 0.2 $\mathrm{M} \mathrm{NH}_{4} \mathrm{OAc}$ ( $\mathrm{pH}$ 6.0).

In the second step, HPEM was labeled with iodine-125 using the chloramine-T method. To a solution of HPEM $(5 \mu \mathrm{g}$; $23 \mathrm{nmol})$ in $\mathrm{MeOH}$ containing $1 \% \mathrm{CH}_{3} \mathrm{COOH}(10 \mu \mathrm{l}),\left[{ }^{125} \mathrm{I}\right] \mathrm{NaI}$ (16 $\mu \mathrm{l}$; 40-60 MBq) and chloramine- $\mathrm{T}\left(5 \mu \mathrm{l}\right.$ of $8 \mathrm{mg} / \mathrm{ml}$ in $\mathrm{H}_{2} \mathrm{O}$; 
$40 \mu \mathrm{g} ; 142 \mathrm{nmol})$ were added. Following incubation at room temperature for $5 \mathrm{~min}$, sodium metabisulfite was added (5 $\mu \mathrm{l}$ of $12 \mathrm{mg} / \mathrm{ml}$ in $\left.\mathrm{H}_{2} \mathrm{O} ; 60 \mu \mathrm{g} ; 316 \mathrm{nmol}\right)$. The labeling yield was determined by radio-TLC analysis, which was performed using silica plates on an aluminum support in ethyl acetate. The radiolabeled HPEM had $\mathrm{Rf}=0.8$, while the free radioiodine remained at the application point.

In the third step, the purified G3-GGGC (550 $\mu \mathrm{g} ; 41 \mathrm{nmol}$; $900 \mu \mathrm{l})$ was added to the [ $\left.{ }^{125} \mathrm{I}\right] \mathrm{I}-\mathrm{HPEM}(5 \mu \mathrm{g} ; 23 \mathrm{nmol})$ in a 1.8:1 molar ratio and incubated at $40^{\circ} \mathrm{C}$ for $1 \mathrm{~h}$. The radiolabeled $\left[{ }^{125} \mathrm{I}\right] \mathrm{I}-\mathrm{HPEM}-\mathrm{G} 3-\mathrm{GGGC}$ was purified using a NAP-5 column, pre-equilibrated and eluted with PBS. The labeling yield was determined by radio-iTLC analysis in a 4:1 acetone: water system.

The in vitro stability test was performed by incubating $\left[{ }^{125} \mathrm{I}\right] \mathrm{I}-\mathrm{HPEM}-\mathrm{G} 3-\mathrm{GGGC}$ and $\left[{ }^{125} \mathrm{I}\right] \mathrm{I}-\mathrm{G} 3-\mathrm{H}_{6}$ with a 5,000-fold molar excess of $\mathrm{KI}$ in $\mathrm{PBS}$ at room temperature for $3 \mathrm{~h}$ (control samples were incubated in PBS). Samples were analyzed by iTLC in 4:1 acetone:water system.

To evaluate the binding affinity of G3-GGGC, it was labeled with $\left[{ }^{125} \mathrm{I}\right] \mathrm{I}$ using direct iodination, as described previously (25). To prevent the formation of dimers via disulfide bonds, the radiolabeled $\left[{ }^{125} \mathrm{I}\right] \mathrm{I}-\mathrm{G} 3-\mathrm{GGGC}(40 \mu \mathrm{g}$; $3 \mathrm{nmol}$ ) was reduced by DTT (46 $\mu \mathrm{g} ; 300 \mathrm{nmol})$ and purified using the NAP-5 column. The terminal cysteine of $\left[{ }^{125} \mathrm{I}\right]$ I-G3-GGGC (11 $\mu \mathrm{g} ; 0.8 \mathrm{nmol})$ was capped by alkylation with iodoacetamide (IAA; $74 \mu \mathrm{g} ; 400 \mathrm{nmol}$ ) at $40^{\circ} \mathrm{C}$ for $30 \mathrm{~min}$. The radiolabeled $\left[{ }^{125} \mathrm{I}\right] \mathrm{I}-\mathrm{G} 3-\mathrm{GGGC}-\mathrm{IAA}$ was purified using the NAP-5 column, pre-equilibrated and eluted with PBS.

Binding specificity and cellular processing assays. In vitro studies were performed using cell lines with high HER2 expression, including SKOV3 (1.6x10 ${ }^{6}$ receptors/cell) (32) and BT474 (1.2x106 receptors/cell) (33), and cells with low HER2

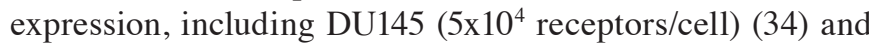
A431 (1.5x10 receptors/cell) (35). Cells were seeded in $3 \mathrm{~cm}$ Petri dishes $\left(\sim 10^{6}\right.$ cells/dish), and three dishes were used for each group.

Binding specificity to HER2 was evaluated as described previously (25). Two sets of dishes were used for each cell line. A 100-fold excess of non-labeled DARPin G3- $\mathrm{H}_{6}(100 \mathrm{nM})$ was added to the first group of cells to saturate the HER2 receptors, and medium only was added to the second group. After $30 \mathrm{~min}$, radiolabeled ${ }^{125} \mathrm{I}[\mathrm{I}]-\mathrm{G} 3-\mathrm{H}_{6}$ or [ $\left.{ }^{125} \mathrm{I}\right] \mathrm{I}-\mathrm{HPEM}-\mathrm{G} 3-\mathrm{GGGC}$ were added to each group at $1 \mathrm{nM}$ concentration. After $1 \mathrm{~h}$ in a humidified incubator at $37^{\circ} \mathrm{C}$, the cell medium was collected, cells were washed with $1 \mathrm{ml}$ of fresh medium and $1 \mathrm{ml}$ of $1 \mathrm{M} \mathrm{NaOH}$ was added to lyse the cells. After $30 \mathrm{~min}$ of incubation, the cell lysate was collected. The radioactivity in each fraction was measured to calculate the percentage of cell-bound radioactivity. The average number of cells per dish at the time of assay was calculated and the value of cell-bound radioactivity was calculated per $10^{6}$ cells. Cellular retention and the processing of radiolabeled proteins by SKOV3 cells was studied during continuous incubation via an acid-wash method (25). The cells ( $1 \times 10^{6}$ cells/dish) were seeded in three dishes for each time point. Radiolabeled DARPins (1 nM) were added to the cells and incubated at $37^{\circ} \mathrm{C}$ in a humidified incubator. At 1, 2, 4, 8 and 24 h post-addition, the medium was collected from one set of dishes and the cells were washed once with serum-free media $(1 \mathrm{ml})$. To collect the membrane-bound
DARPins, the cells were treated with $0.2 \mathrm{M}$ glycine buffer containing $4 \mathrm{M}$ urea, $\mathrm{pH} 2.0(1 \mathrm{ml})$ on ice for $5 \mathrm{~min}$, the buffer was collected, and the cells were washed once with the same buffer $(1 \mathrm{ml})$. To collect the internalized DARPins, the cells were treated with $1 \mathrm{M} \mathrm{NaOH}(1 \mathrm{ml})$ for $30 \mathrm{~min}$, following which the cells were collected and washed with an additional $1 \mathrm{ml}$. The activity in every fraction was measured. The percentage of cell-associated activity was calculated. The maximum value of cell-associated activity in each dataset (individually for $\left[{ }^{125} \mathrm{I}\right] \mathrm{I}-\mathrm{HPEM}-\mathrm{G} 3-\mathrm{GGGC}$ and for $\left[{ }^{125} \mathrm{I}\right] \mathrm{I}-\mathrm{G} 3-\mathrm{H}_{6}$ ) was taken as $100 \%$ and the data were normalized to this.

Affinity measurements using LigandTracer. The binding kinetics of radiolabeled DARPins [ $\left.{ }^{125} \mathrm{I}\right] \mathrm{I}-\mathrm{G} 3-\mathrm{H}_{6},\left[{ }^{125} \mathrm{I}\right] \mathrm{I}-\mathrm{G} 3-\mathrm{GGGC}-\mathrm{IAA}$ and $\left[{ }^{125} \mathrm{I}\right] \mathrm{I}-\mathrm{HPEM}-\mathrm{G} 3-\mathrm{GGGC}$ to living SKOV3 cells was measured using LigandTracer (Ridgeview Instruments AB, Vänge, Sweden) as described previously (36). Kinetics of binding to and dissociation from cells were recorded at room temperature in real time. Increasing concentrations of radiolabeled DARPins ( 0.5 and $2 \mathrm{nM}$ ) were added to cells followed by replacement of the medium and measurements of retention in the dissociation phase. TraceDrawer Software (version 1.7.1; Ridgeview Instruments $\mathrm{AB}$ ) was used to calculate the dissociation constants based on the association and dissociation rates.

Animal studies. The animal experiments were planned and performed in accordance with national legislation on laboratory animal protection. The animal studies were approved by the local ethics committee for animal research in Uppsala, Sweden (Uppsala djurgörsöketiska nämnd), decision no. C4/2016.

Female BALB/c nu/nu mice $(n=14)$ of 6 weeks old, with an average weight at arrival of 16-17 $\mathrm{g}$, were supplied from Scanbur A/S (Karlslunde, Denmark). Mice were housed in standard conditions at $22^{\circ} \mathrm{C}, 48 \%$ humidity, with a $12 / 12 \mathrm{~h}$ light/dark cycle. Standard laboratory food and water were provided ad libitum. Mice had an adaptation period of 1 week prior to the start of the experimental procedures. For the implantation of tumors, $10^{7}$ of SKOV3 cells with high HER2 expression or $5 \times 10^{6}$ of A431 cells with low HER 2 expression in $100 \mu \mathrm{l}$ media were subcutaneously injected in the right hind leg. The experiments were performed two and a half weeks after implantation. The average animal weight at the time of sacrifice was $19 \pm 0 \mathrm{~g}$ in the SKOV3 group, $18 \pm 1 \mathrm{~g}$ in the A431 group. The average tumor weight in the biodistribution studies was $0.08 \pm 0.03 \mathrm{~g}$ for SKOV3 xenografts and $0.16 \pm 0.06 \mathrm{~g}$ for A431 xenografts. The maximum tumor diameter (in the imaging studies) was $1.0 \mathrm{~cm}$ in the SKOV3 group and $1.1 \mathrm{~cm}$ in the A431 group. The tumor volume was $<1 \mathrm{~cm}^{3}$. No multiple tumors were observed. For the comparative biodistribution of $\left[{ }^{131} \mathrm{I}\right] \mathrm{I}-\mathrm{G} 3-\mathrm{H}_{6}$ and [ $\left.{ }^{125} \mathrm{I}\right] \mathrm{I}-\mathrm{HPEM}-\mathrm{G} 3-\mathrm{H}_{6}-\mathrm{GGGC}$, a dual-label approach was used. The mice were intravenously injected with a mixture of $\left[{ }^{131} \mathrm{I}\right] \mathrm{I}-\mathrm{G} 3-\mathrm{H}_{6}$ and $\left[{ }^{125} \mathrm{I}\right] \mathrm{I}-\mathrm{HPEM}-\mathrm{G} 3-\mathrm{H}_{6}-\mathrm{GGGC}$ in $100 \mu \mathrm{l}$ of $1 \%$ bovine serum albumin (Sigma-Aldrich; Merck KGaA) in PBS per mouse $\left(27 \mathrm{kBq}\right.$ for $\left[{ }^{131} \mathrm{I}\right] \mathrm{I}-\mathrm{G} 3-\mathrm{H}_{6}$, $20 \mathrm{kBq}$ for $\left.\left[{ }^{125} \mathrm{I}\right] \mathrm{I}-\mathrm{HPEM}-\mathrm{G} 3-\mathrm{H}_{6}-\mathrm{GGGC}\right)$. In addition, the biodistribution of [ $\left.{ }^{125} \mathrm{I}\right] \mathrm{I}-\mathrm{G} 3-\mathrm{H}_{6}$ was studied in SKOV-3-bearing $\mathrm{BALB} / \mathrm{c}$ nu/nu mice with $\mathrm{Na} / \mathrm{I}$-symporters blocked by supplementation of drinking water with $1 \%$ KI 3 days prior to the experiment. The injected protein amount was adjusted to $4 \mu \mathrm{g}$ by non-labeled $\mathrm{G} 3-\mathrm{H}_{6}$. At $4 \mathrm{~h}$ post-injection (pi) mice 
Table I. Labeling of designed ankyrin repeat proteins $\mathrm{G} 3-\mathrm{H}_{6}$ and G3-GGGC using direct and indirect radioiodination.

\begin{tabular}{llccr}
\hline Labeling method & \multicolumn{1}{c}{ Labeled protein } & Radionuclide & Radiochemical yield, \% & Radiochemical purity, \% \\
\hline Direct random labeling & $\mathrm{G} 3-\mathrm{H}_{6}$ & ${ }^{125} \mathrm{I}$ & $98 \pm 1(\mathrm{n}=3)$ & $99 \pm 1(\mathrm{n}=3)$ \\
& $\mathrm{G} 3-\mathrm{H}_{6}$ & ${ }^{124} \mathrm{I}$ & $87(\mathrm{n}=1)$ & $99(\mathrm{n}=1)$ \\
& $\mathrm{G} 3-\mathrm{H}_{6}$ & ${ }^{131} \mathrm{I}$ & $99(\mathrm{n}=1)$ & $99(\mathrm{n}=1)$ \\
Indirect site-specific labeling & G3-GGGC & ${ }^{125} \mathrm{I}$ & $31 \pm 1$ & $95 \pm 0(\mathrm{n}=2)$ \\
& $($ conjugated to HPEM) & & $(\mathrm{n}=2$, overall yield) & \\
\hline
\end{tabular}

HPEM, [(4-hydroxyphenyl)ethyl]maleimide.

were anesthetized by an intraperitoneal injection of ketamine and xylazine solution and sacrificed by heart puncture. The dose of ketamine was $250 \mathrm{mg} / \mathrm{kg}$, and the dose of xylazine was $25 \mathrm{mg} / \mathrm{kg}$. The average volume of blood collected by cardiac puncture with a heparinized syringe was $0.7 \pm 0.2 \mathrm{ml}$. The salivary glands, lungs, liver, spleen, stomach (without contents), kidneys, tumor, samples of muscle and bone from the contralateral leg to the tumor implantation site, the gastrointestinal tract with contents and the tail were harvested. Organs were weighed and activity was measured using an automated $\gamma$-spectrometer. The percentage of injected dose per gram of sample $(\% \mathrm{ID} / \mathrm{g})$ was calculated. Data for the intestines with contents and carcass were calculated as \%ID per whole sample. Spectra of standards and samples were recorded. For the dual-isotope study, the activities of iodine-125 and iodine-131 were calculated by integration of the counts in the energy ranges $5-100 \mathrm{keV}$ and $150-500 \mathrm{keV}$, respectively. The data were corrected for dead time of the $\gamma$-spectrometer, background and spillover of iodine-131 counts into the iodine-125 energy window.

PET and SPECT imaging was performed to obtain visual confirmation of the ex vivo biodistribution measurements. A total of 3 days before the imaging, the drinking water was supplemented with $1 \%$ potassium iodide.

The SPECT study was performed using ${ }^{125} \mathrm{I}$-labeled $\mathrm{G} 3-\mathrm{H}_{6}$. Although ${ }^{131} \mathrm{I}$ is also potentially suitable for SPECT imaging, it emits high energy $\gamma$ quanta (364 and $637 \mathrm{keV}$ ) (37). This requires a specialized high-energy whole-body collimator, which was not available in the device used in the present study. Therefore, the low-energy $\gamma$ emitter ${ }^{125} \mathrm{I}$ was used as the label.

A mouse bearing SKOV3 xenografts with high HER2 expression was injected with [ $\left.{ }^{125} \mathrm{I}\right] \mathrm{I}-\mathrm{G} 3-\mathrm{H}_{6}(7 \mu \mathrm{g} ; 19.7 \mathrm{MBq})$. The SPECT imaging was performed using nanoScan SPECT/CT (Mediso Medical Imaging Systems Ltd., Budapest, Hungary) at 1,2 and $4 \mathrm{~h}$ post-injection. The acquisition time was $15 \mathrm{~min}$. CT scans were acquired using the following parameters: X-ray energy peak of $50 \mathrm{keV} ; 670 \mu \mathrm{A} ; 480$ projections; and $5.26 \mathrm{~min}$ acquisition time. A mouse bearing A431 xenografts with low HER2 expression was injected with $\left[{ }^{125} \mathrm{I}\right] \mathrm{I}-\mathrm{G} 3-\mathrm{H}_{6}(7 \mu \mathrm{g}$, 19.7 MBq). The imaging was performed at $4 \mathrm{~h}$ post-injection using the same settings as those for the mouse bearing the SKOV-3 xenograft. SPECT raw data were reconstructed using Tera-Tomo ${ }^{\mathrm{TM}}$ 3D SPECT reconstruction technology (version 3.00.020.000; Mediso Medical Imaging Systems Ltd.): Normal dynamic range; 48 iterations; 1 subset. The area corresponding to the activity in the urinary bladder was removed from the SPECT image following reconstruction to facilitate better visualization of tumor uptake. CT data were reconstructed using Filter Back Projection in Nucline 2.03 Software (Mediso Medical Imaging Systems Ltd.). SPECT and CT files were fused using Nucline 2.03 Software and are presented as maximum intensity projections (MIP) in the RGB color scale.

Whole-body PET imaging was performed using nanoScan PET/MRI (Mediso Medical Imaging System). A mouse bearing SKOV3 xenografts was injected with $\left[{ }^{124} \mathrm{I}\right]$ I-G3-H $-\mathrm{H}_{6}(7 \mu \mathrm{g} ; 4.7 \mathrm{MBq})$ and imaged at $4 \mathrm{~h}$ pi. The PET scan was performed for $90 \mathrm{~min}$; subsequently, the CT scan was performed using nanoScan SPECT/CT (Mediso Medical Imaging Systems Ltd.) using the same bed position as for the PET scan. The CT scan was acquired using the same parameters as for the SPECT/CT images and the CT data were reconstructed in the same way. PET data were reconstructed using the Tera- 3D reconstruction engine. PET and CT files were fused using Nucline 2.03 Software and are presented as maximum intensity projections (MIP) in the RGB color scale.

Statistical analysis of the data. The in vitro specificity and cell processing data are presented as the mean \pm standard deviation of three samples. The data were analyzed using an unpaired two-tailed t-test to find the significant differences. A paired two-tailed t-test was performed using GraphPad Prism (version 7.02; GraphPad Software, Inc., La Jolla, CA, USA) for analysis of the biodistribution data from the dual-label study to find significant differences. $\mathrm{P}<0.05$ was considered to indicate a statistically significant difference.

\section{Results}

Radiolabeling and stability. A total of two methods for the radio-iodination of DARPin G3 variants were used: Direct labeling of $\mathrm{G} 3-\mathrm{H}_{6}$ and indirect labeling of G3-GGGC using a HPEM linker. The data concerning the isolated radiochemical yields and radiochemical purity of the conjugates are presented in Table I.

Direct labeling of $\mathrm{G} 3-\mathrm{H}_{6}$ with iodine-125 was performed as described previously for DARPin 9_29 (22), with a high radiochemical yield. Size-exclusion chromatography on a NAP-5 column provided radiolabeled proteins with a radiochemical purity $>98 \%$. For the biodistribution studies and imaging, direct iodination of $\mathrm{G} 3-\mathrm{H}_{6}$ with iodine-131 and iodine-124 was performed using the same labeling protocol 


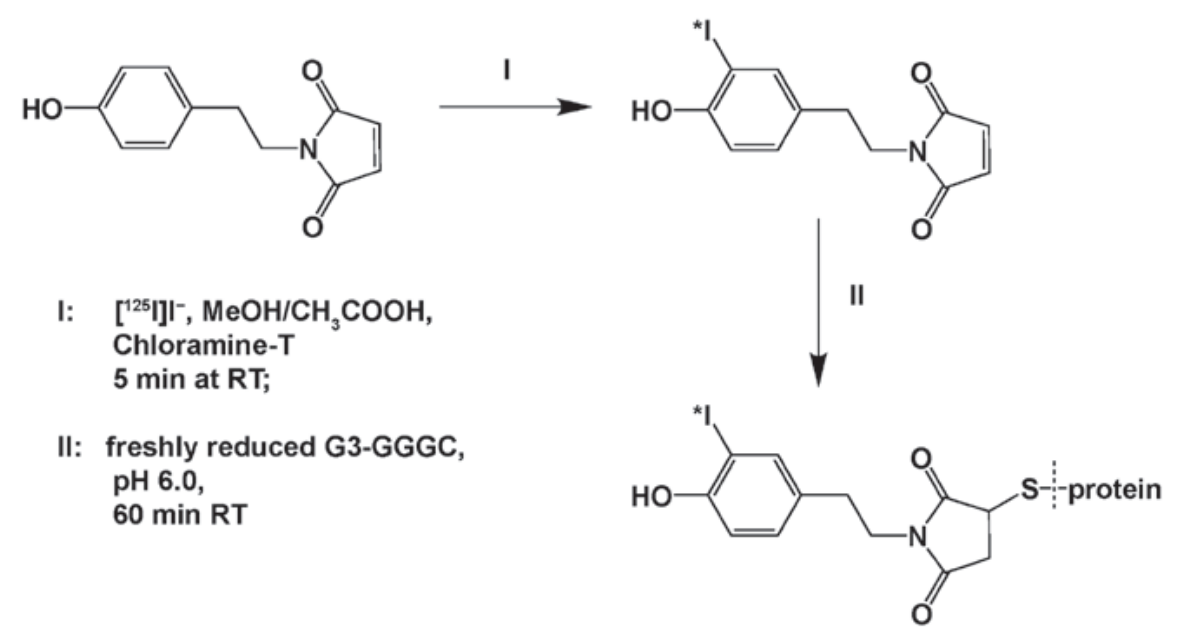

Figure 1. Site-specific radioiodination of G3-GGGC is a one-pot reaction achieved in two steps without intermediate purification. In the first step, HPEM is iodinated using chloramine T; in the second step, HPEM is attached to the protein using maleimide-cysteine coupling. HPEM, (4-hydroxyphenyl)ethyl) maleimide; RT, room temperature.

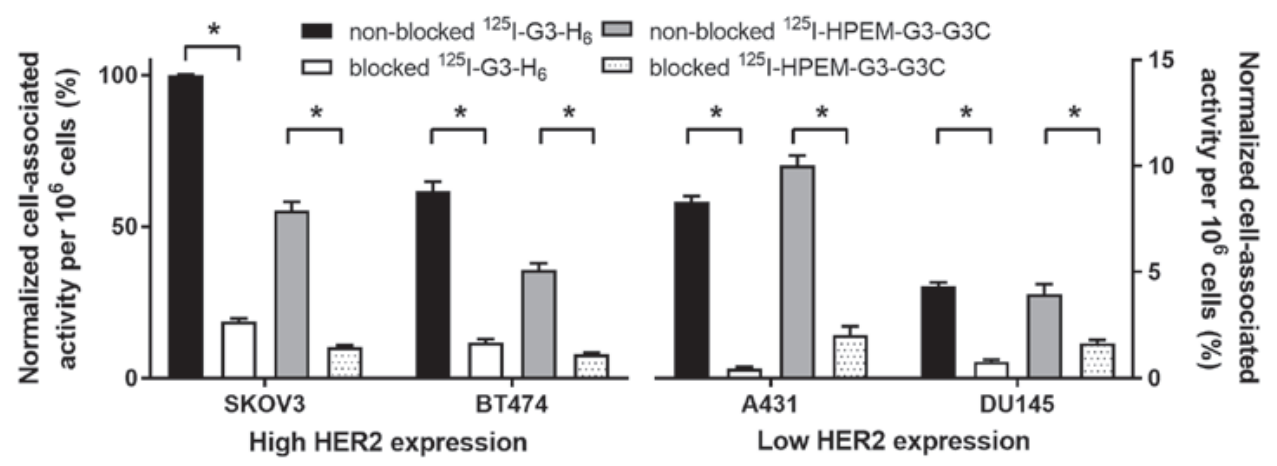

Figure 2. Specificity of [ $\left.{ }^{125} \mathrm{I}\right] \mathrm{I}-\mathrm{G} 3-\mathrm{H}_{6}$ and $\left[{ }^{125} \mathrm{I}\right] \mathrm{I}-\mathrm{HPEM}-\mathrm{G} 3-\mathrm{GGGC}$ binding to cancer cell lines with high (SKOV3, BT474) and low (A431, DU145) levels of HER2 expression in vitro. Radiolabeled compounds were added at a $1 \mathrm{nM}$ concentration; 100 -fold molar excess of non-labeled $\mathrm{G} 3-\mathrm{H}_{6}$ was added to the blocked groups. Data are presented as the mean \pm standard deviation from three samples. The uptake of each compound in the non-blocked group was compared with the uptake in the blocked group in each cell line individually. ${ }^{*}$ < 0.05 . HPEM, (4-hydroxyphenyl)ethyl) maleimide; HER2, human epidermal growth factor receptor 2.

with good radiochemical yields. Purification using a NAP-5 column provided $\left[{ }^{131} \mathrm{I}\right] \mathrm{I}-\mathrm{G} 3-\mathrm{H}_{6}$ and $\left[{ }^{131} \mathrm{I}\right] \mathrm{I}-\mathrm{G} 3-\mathrm{H}_{6}$ with $99 \%$ radiochemical purity.

Indirect labeling was performed as a one-pot procedure in two steps without intermediate purification (Fig. 1). First, a bifunctional linker with an activated phenolic ring and a maleimide group (HPEM) was iodinated, with a resulting radiochemical yield of $95 \pm 3 \%$. Subsequently, $\left[{ }^{125} \mathrm{I}\right] \mathrm{I}-\mathrm{HPEM}$ was conjugated to G3-GGGC with an overall radiochemical yield of $31 \pm 1 \%$. The radiolabeled conjugate was purified on a NAP-5 column with radiochemical purity of $95 \pm 0 \%$. Specific activity of $33 \mathrm{kBq} / \mu \mathrm{g}$ was achieved.

Radio-HPLC analysis of $\left[{ }^{125} \mathrm{I}\right] \mathrm{I}-\mathrm{G} 3-\mathrm{H}_{6}$ and $\left[{ }^{125} \mathrm{I}\right]$ I-HPEM-G3-GGGC illustrated a single peak at $14.5 \mathrm{~min}$. Incubation of $\left[{ }^{125} \mathrm{I}\right] \mathrm{I}-\mathrm{G} 3-\mathrm{H}_{6}$ and $\left[{ }^{125} \mathrm{I}\right] \mathrm{I}-\mathrm{HPEM}-\mathrm{G} 3-\mathrm{GGGC}$ with a 5,000-fold molar excess of cold iodide did not demonstrate any measurable release of the labeled compound compared with the PBS control (Table II).

In vitro studies. Binding specificity of $\left[{ }^{125} \mathrm{I}\right] \mathrm{I}-\mathrm{G} 3-\mathrm{H}_{6}$ and $\left[{ }^{125} \mathrm{I}\right]$ I-HPEM-G3-GGGC to HER2 was evaluated in cancer cell lines possessing different levels of HER2 expression (Fig. 2). Saturable character binding of the two radiolabeled DARPins to HER2 demonstrated specificity. Cell-bound activity was proportional to the level of HER2 expression in cells, and was higher for SKOV3 and BT474 compared with A431 and DU145 cells.

The binding kinetics of $\left[{ }^{125} \mathrm{I}\right] \mathrm{I}-\mathrm{G} 3-\mathrm{H}_{6},\left[{ }^{125} \mathrm{I}\right] \mathrm{I}-\mathrm{G} 3-\mathrm{GGGC}-\mathrm{IAA}$ and [ $\left.{ }^{125} \mathrm{I}\right] \mathrm{I}-\mathrm{HPEM}-\mathrm{G} 3-\mathrm{GGGC}$ to HER2-expressing SKOV3 cells was measured using LigandTracer. The binding of all labeled G3 variants to living cells was best fitted to a 1:2 interaction model, as previously published for the anti-HER2 DARPin 9_29 (25). Two types of interactions were observed: A high affinity interaction in the picomolar range, and a low affinity interaction in the single digit nanomolar range (Table III). The same types of binding interactions have been previously observed for DARPin 9_29 (25). All three variants had similar values for the high affinity interaction, and the [ $\left.{ }^{125} \mathrm{I}\right] \mathrm{I}-\mathrm{G} 3-\mathrm{GGGC}-\mathrm{IAA}$ had a slightly lower dissociation constant for the second interaction. These data confirmed that $\left[{ }^{125} \mathrm{I}\right] \mathrm{I}-\mathrm{G} 3-\mathrm{H}_{6}$ had the same binding affinity to HER2 as [ $\left.{ }^{125} \mathrm{I}\right] \mathrm{I}-\mathrm{HPEM}-\mathrm{G} 3-\mathrm{GGGC}$, and that the direct iodination had no adverse effect on binding.

The processing of radiolabeled DARPins by HER2expressing SKOV3 cells is illustrated in Fig. 3. The pattern of processing was typical for a non-residualizing label with a low internalized fraction for the two proteins. The decrease in cell-associated activity following maximal accumulation was 
Table II. In vitro stability of $\left[{ }^{125} \mathrm{I}\right] \mathrm{I}-\mathrm{HPEM}-\mathrm{G} 3-\mathrm{GGGC}$ and [ $\left.{ }^{125} \mathrm{I}\right] \mathrm{I}-\mathrm{G} 3-\mathrm{H}_{6}$.

\begin{tabular}{|c|c|c|c|c|}
\hline \multirow[b]{3}{*}{ Test solution } & \multicolumn{4}{|c|}{ DARPin-associated activity, \% } \\
\hline & \multicolumn{2}{|c|}{$\left[{ }^{125} \mathrm{I}\right] \mathrm{I}-\mathrm{HPEM}-\mathrm{G} 3-\mathrm{GGGC}$} & \multicolumn{2}{|c|}{$\left[{ }^{125} \mathrm{I}\right] \mathrm{I}-\mathrm{G} 3-\mathrm{H}_{6}$} \\
\hline & $1 \mathrm{~h}$ & $3 \mathrm{~h}$ & $1 \mathrm{~h}$ & $3 \mathrm{~h}$ \\
\hline PBS (control) & $97 \pm 1$ & $97 \pm 1$ & $99 \pm 0$ & $99 \pm 0$ \\
\hline $5,000 X \mathrm{KI}$ & $98 \pm 0$ & $95 \pm 2$ & $99 \pm 0$ & $99 \pm 0$ \\
\hline
\end{tabular}

Analysis was performed in duplicate. HPEM, [(4-hydroxyphenyl) ethyl]maleimide; DARPin, designed ankyrin repeat protein.
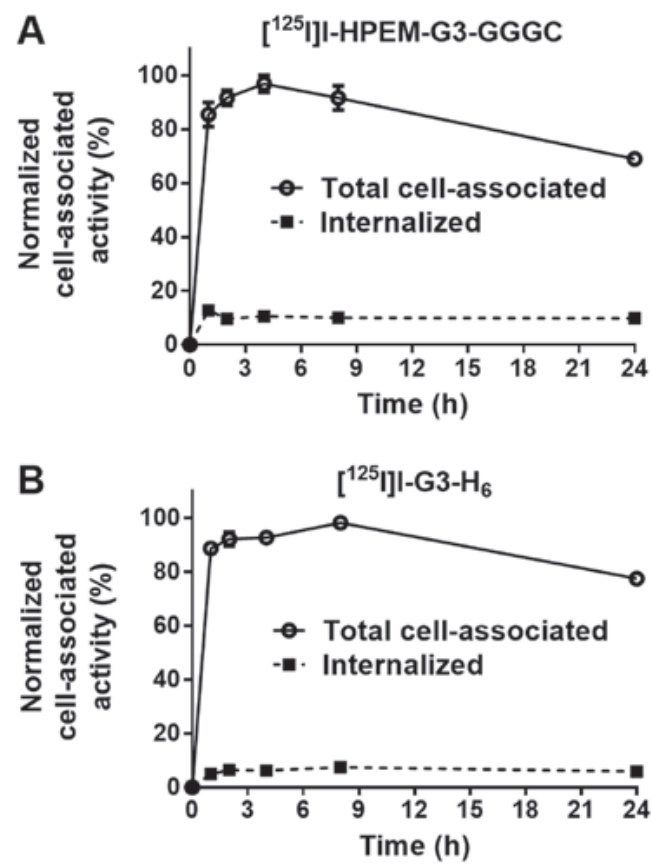

Figure 3. In vitro characterization of radio-iodinated $\mathrm{G} 3$ variants. Cellular processing of (A) $\left[{ }^{125} \mathrm{I}\right] \mathrm{I}-\mathrm{HPEM}-\mathrm{G} 3-\mathrm{GGGC}$ and (B) $\left[{ }^{125} \mathrm{I}\right] \mathrm{I}-\mathrm{G} 3-\mathrm{H}_{6}$ by human epidermal growth factor receptor 2-expressing SKOV3 cells during continuous incubation over $24 \mathrm{~h}$. Data are presented as the mean \pm standard deviation from three samples; error bars may not be visible when they are smaller than symbols. HPEM, (4-hydroxyphenyl)ethyl) maleimide.

due to the release of radiocatabolites from cells. Cell-associated activity was $>85 \%$ of the maximum between 1 and $8 \mathrm{~h}$ post-addition.

Animal studies. To study the biodistribution of radio-iodinated proteins side-by-side in vivo, a dual isotope approach was used. HPEM-G3-GGGC was labeled with iodine- 125 and $\mathrm{G} 3-\mathrm{H}_{6}$ was labeled with iodine-131. Biodistribution and tumor targeting were studied in BALB/C nu/nu mice bearing HER2-expressing SKOV3 xenografts at $4 \mathrm{~h}$ pi (Fig. 4). The two radiolabeled DARPins had fast clearance from the blood and low retention in excretory organs. Notably, $\left[{ }^{125} \mathrm{I}\right] \mathrm{I}-\mathrm{HPEM}-\mathrm{G} 3-\mathrm{GGGC}$ demonstrated 2-fold lower accumulation in tumors compared with $\left[{ }^{131} \mathrm{I}\right] \mathrm{I}-\mathrm{G} 3-\mathrm{H}_{6}(3.7 \pm 1.0$ vs. $8.2 \pm 2.0 \% \mathrm{ID} / \mathrm{g} ; \mathrm{P}=0.003$; paired $\mathrm{t}$-test). Besides lower tumor uptake, a low level of iodine-125 radiocatabolites was observed in organs with expression
Table III. Dissociation equilibrium constants $\left(\mathrm{K}_{\mathrm{D}}\right)$ for the interaction between radiolabeled designed ankyrin repeat proteins and human epidermal growth factor receptor 2-expressing SKOV3 cells.

\begin{tabular}{lcc}
\hline & $\mathrm{K}_{\mathrm{D} 1}(\mathrm{pM})$ & $\mathrm{K}_{\mathrm{D} 2}(\mathrm{nM})$ \\
\hline$\left.{ }^{[25} \mathrm{I}\right] \mathrm{I}-H P E M-G 3-G G G C(\mathrm{n}=3)$ & $99 \pm 5$ & $3.5 \pm 0.4$ \\
$\left.{ }^{[25} \mathrm{I}\right] \mathrm{I}-G 3-G G G C-I A A(\mathrm{n}=2)$ & $146 \pm 20$ & $1.5 \pm 0.4$ \\
$\left.{ }^{125} \mathrm{I}\right] \mathrm{I}-\mathrm{G} 3-\mathrm{H}_{6}(\mathrm{n}=3)$ & $163 \pm 41$ & $3.9 \pm 1.5$ \\
\hline
\end{tabular}

HPEM, [(4-hydroxyphenyl)ethyl]maleimide

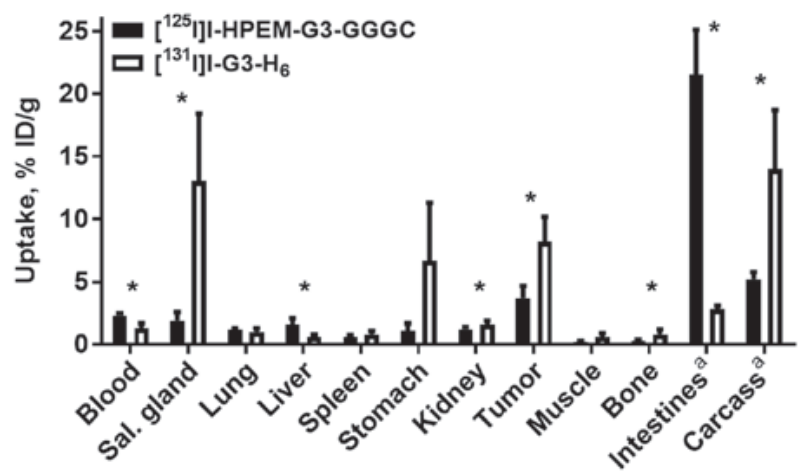

Figure 4. Comparative biodistribution of $\left[{ }^{125} \mathrm{I}\right] \mathrm{I}-\mathrm{HPEM}-\mathrm{G} 3-\mathrm{GGGC}$ and $\left.{ }^{[31} \mathrm{I}\right] \mathrm{I}-\mathrm{G} 3-\mathrm{H}_{6}$ at $4 \mathrm{~h}$ pi in BALB/C nu/nu mice bearing human epidermal growth factor receptor 2-expressing SKOV3 xenografts. Data are presented as the mean \pm standard deviation from four mice. An asterisk marks a significant difference between values. ${ }^{*} \mathrm{P}<0.05$. ${ }^{\mathrm{a}} \mathrm{D}$ ata for intestines with content and carcass are presented as \%ID per whole sample. HPEM, (4-hydroxyphenyl) ethyl) maleimide; sal. gland, salivary gland; ID, injected dose.

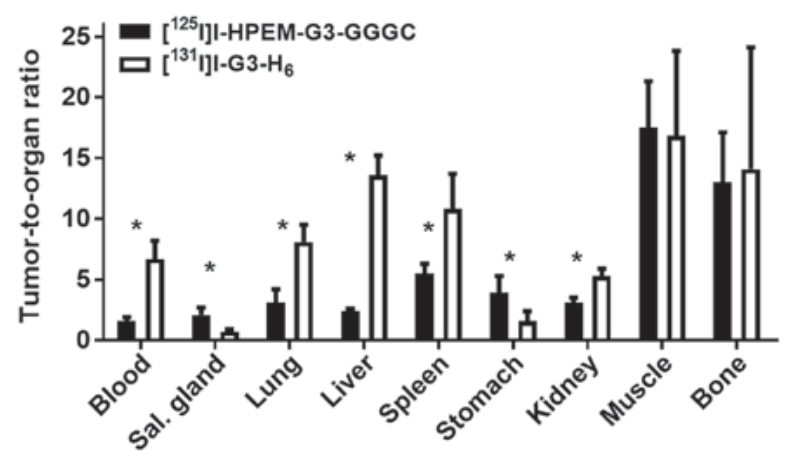

Figure 5. Comparison of tumor-to-organ ratios for [ $\left.{ }^{125} \mathrm{I}\right] \mathrm{I}-\mathrm{HPEM}-\mathrm{G} 3-\mathrm{GGGC}$ and $\left[{ }^{131} \mathrm{I}\right] \mathrm{I}-\mathrm{G} 3-\mathrm{H}_{6}$ at $4 \mathrm{~h}$ pi in BALB/C nu/nu mice bearing SKOV3 xenografts Data are presented as the mean \pm standard deviation from four mice. ${ }^{*} \mathrm{P}<0.05$. HPEM, (4-hydroxyphenyl)ethyl) maleimide; sal. gland, salivary gland.

of $\mathrm{Na} / \mathrm{I}$-symporters (salivary glands, stomach) compared with iodine-131. Accumulation of iodine-125 activity in the intestines was approximately seven times higher compared with that for iodine-131.

High tumor accumulation of $\left[{ }^{131} \mathrm{I}\right] \mathrm{I}-\mathrm{G} 3-\mathrm{H}_{6}$ resulted in significantly $(\mathrm{P}<0.05$, determined by paired $t$ test $)$ higher tumor-to-organ ratios for the majority of organs, apart from organs expressing sodium-iodide symporters, muscles and bones, in comparison with [125I]I-HPEM-G3-GGGC (Fig. 5). 

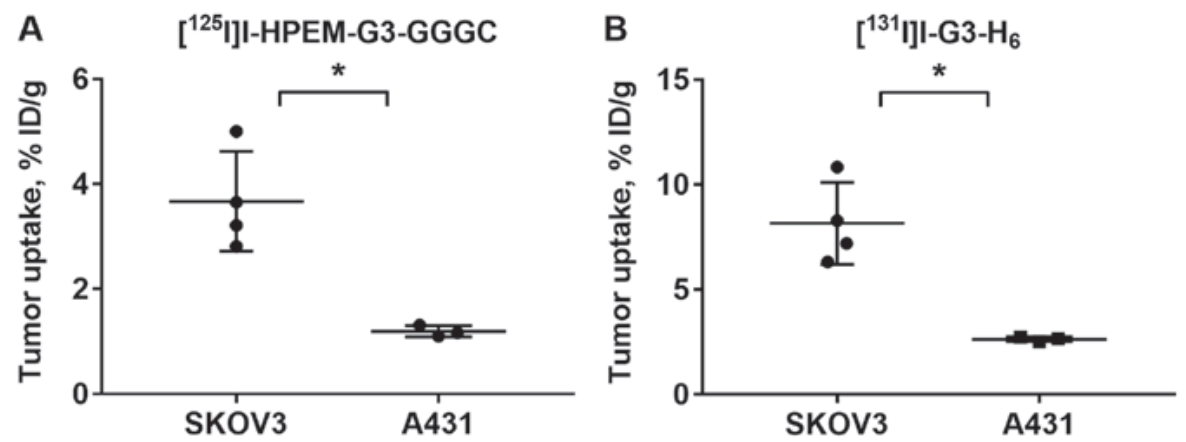

Figure 6. Tumor-targeting specificity of (A) [ $\left.{ }^{125} \mathrm{I}\right] \mathrm{I}-\mathrm{HPEM}-\mathrm{G} 3-\mathrm{GGGC}$ and (B) $\left[{ }^{131} \mathrm{I}\right] \mathrm{I}-\mathrm{G} 3-\mathrm{H}_{6}$ in SKOV3 xenografts (n=4; high HER2 expression) and A431 xenografts ( $\mathrm{n}=3$; low HER2 expression). Data are presented as the mean \pm standard deviation. " $\mathrm{P}<0.05$. HPEM, (4-hydroxyphenyl)ethyl) maleimide; ID, injected dose; HER2, human epidermal growth factor receptor 2.

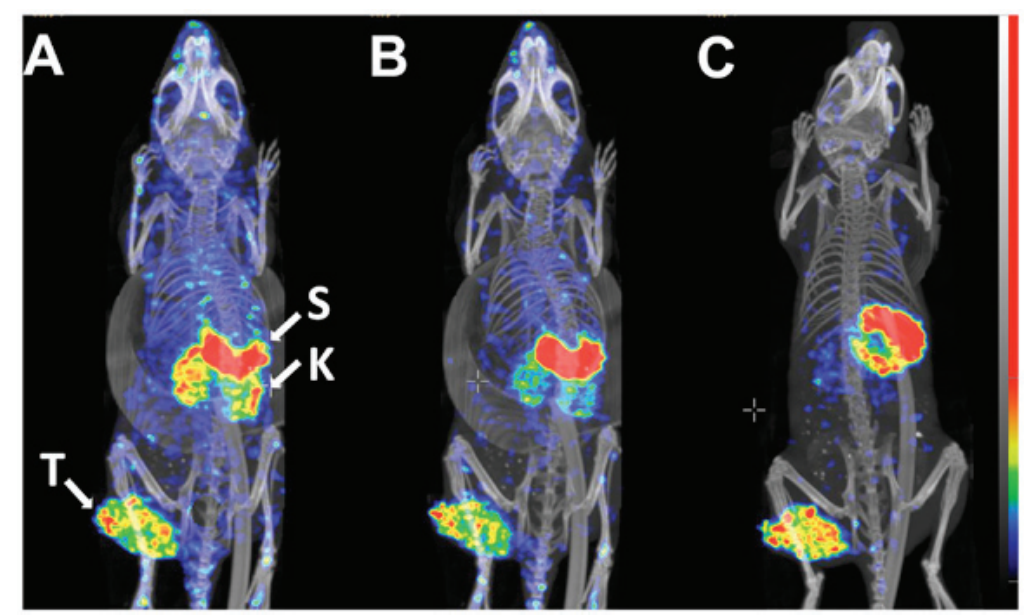

Figure 7. Imaging of HER 2 expression in mice bearing SKOV3 xenografts at 1, 2 and $4 \mathrm{~h}$. Micro-single photon emission computed tomography/computed tomography imaging of human epidermal growth factor receptor 2 expression in BALB/C nu/nu mice bearing SKOV3 xenograft at (A) 1, (B) 2 and (C) $4 \mathrm{~h}$ post-injection using $\left[{ }^{125} \mathrm{I}\right] \mathrm{I}-\mathrm{G} 3-\mathrm{H}_{6}$. The uptake of radiocatabolites by Na/I-symporters was blocked by addition of KI in drinking water. The area corresponding to the activity in urinary bladder was removed from the 1 and $2 \mathrm{~h}$ images during reconstruction to enable better visualization of tumor uptake. S, stomach; K, kidneys; T, tumor.

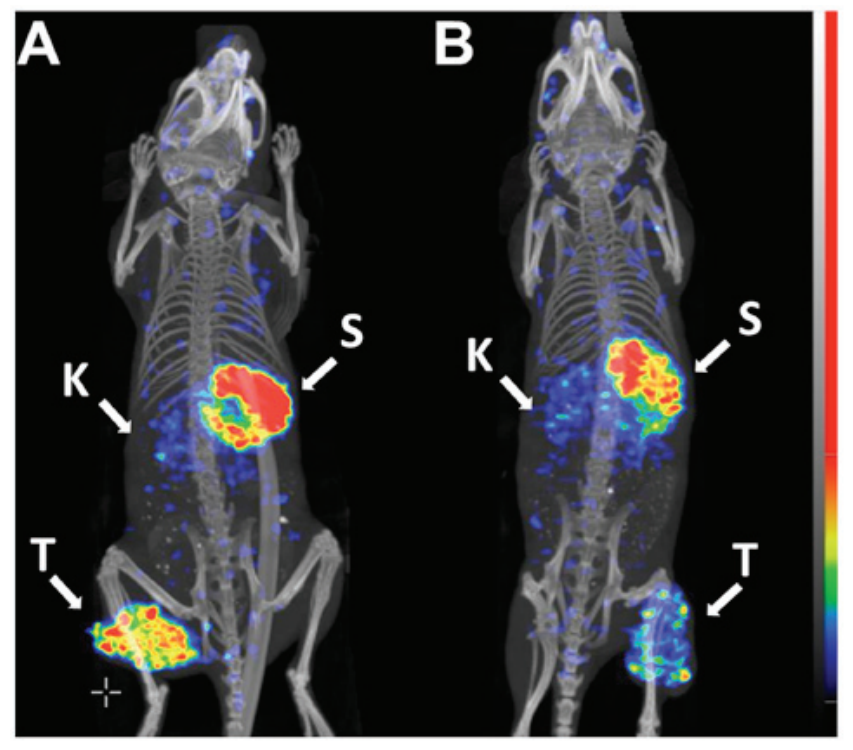

Figure 8. Comparative imaging of high (SKOV3) and low (A431) HER2expressing xenografts in mice. Micro-single photon emission computed tomography/computed tomography imaging of human epidermal growth factor receptor 2 expression in BALB/C nu/nu mice bearing (A) SKOV3 and (B) A431 xenografts at $4 \mathrm{~h}$ post-injection using $\left.{ }^{[25} \mathrm{I}\right] \mathrm{I}-\mathrm{G} 3-\mathrm{H}_{6}$. The uptake of radiocatabolites by $\mathrm{Na} / \mathrm{I}$-symporters was blocked by addition of $\mathrm{KI}$ in drinking water. S, stomach; K, kidneys; T, tumor.

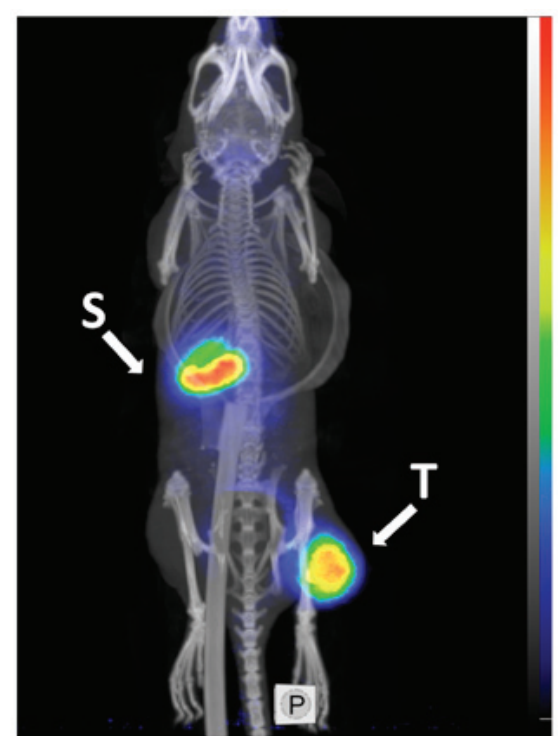

Figure 9. MicroPET/computed tomography imaging of human epidermal growth factor receptor 2 expression in BALB/C nu/nu mouse bearing SKOV3 xenograft at $4 \mathrm{~h}$ post-injection using $\left.{ }^{[24} \mathrm{I}\right] \mathrm{I}-\mathrm{G} 3-\mathrm{H}_{6}$. The uptake of radiocatabolites by $\mathrm{Na} / \mathrm{I}$-symporters was blocked by addition of $\mathrm{KI}$ in drinking water. The area corresponding to the activity in urinary bladder was removed from the PET image during reconstruction to enable better visualization of tumor uptake. S, stomach; T, tumor; PET, positron emission tomography. 
Table IV. Biodistribution and tumor-to-organ ratios of [ $\left.{ }^{125} \mathrm{I}\right] \mathrm{I}-\mathrm{G} 3-\mathrm{H}_{6}\left(\mathrm{Na} / \mathrm{I}-\right.$ symporters were blocked by cold KI) and $\left[{ }^{131} \mathrm{I}\right] \mathrm{I}-\mathrm{G} 3-\mathrm{H}_{6}$ (no blockade of $\mathrm{Na} / \mathrm{I}$-symporters) at $4 \mathrm{~h}$ post-injection in BALB/C nu/nu mice bearing SKOV3 xenografts.

\begin{tabular}{|c|c|c|c|c|}
\hline Location & $\begin{array}{c}\text { Uptake of } \\
{\left[{ }^{125} \mathrm{I}\right] \mathrm{I}-\mathrm{G} 3-\mathrm{H}_{6},} \\
\% \mathrm{ID} / \mathrm{g}\end{array}$ & $\begin{array}{c}\text { Tumor-to-organ } \\
\text { ratio for } \\
{\left[{ }^{125} \mathrm{I}\right] \mathrm{I}-\mathrm{G} 3-\mathrm{H}_{6}}\end{array}$ & $\begin{array}{c}\text { Uptake of } \\
{\left[{ }^{131} \mathrm{I}\right] \mathrm{I}-\mathrm{G} 3-\mathrm{H}_{6},} \\
\% \mathrm{ID} / \mathrm{g}\end{array}$ & $\begin{array}{c}\text { Tumor-to-organ } \\
\text { ratio for } \\
{\left[{ }^{131} \mathrm{I}\right] \mathrm{I}-\mathrm{G} 3-\mathrm{H}_{6}}\end{array}$ \\
\hline Blood & $0.3 \pm 0.1^{\mathrm{a}}$ & $37 \pm 13^{a}$ & $1.3 \pm 0.4$ & $7 \pm 2$ \\
\hline Salivary glands & $0.23 \pm 0.08^{\mathrm{a}}$ & $45 \pm 14^{\mathrm{a}}$ & $13.0 \pm 5.4$ & $0.7 \pm 0.2$ \\
\hline Lung & $0.4 \pm 0.1^{\mathrm{a}}$ & $29 \pm 8^{\mathrm{a}}$ & $1.0 \pm 0.3$ & $8 \pm 1$ \\
\hline Liver & $0.16 \pm 0.05^{\mathrm{a}}$ & $48 \pm 22^{\mathrm{a}}$ & $0.6 \pm 0.2$ & $14 \pm 2$ \\
\hline Spleen & $0.22 \pm 0.07^{\mathrm{a}}$ & $48 \pm 13^{\mathrm{a}}$ & $0.8 \pm 0.3$ & $11 \pm 3$ \\
\hline Stomach & $0.6 \pm 0.2^{\mathrm{a}}$ & $18 \pm 7^{\mathrm{a}}$ & $6.7 \pm 4.6$ & $2 \pm 1$ \\
\hline Kidney & $1.5 \pm 0.4$ & $6.7 \pm 1.4$ & $1.6 \pm 0.3$ & $5.3 \pm 0.6$ \\
\hline Muscle & $0.19 \pm 0.03^{\mathrm{a}}$ & $53 \pm 9^{a}$ & $0.6 \pm 0.3$ & $17 \pm 7$ \\
\hline Bone & $0.4 \pm 0.2$ & $33 \pm 25$ & $0.8 \pm 0.4$ & $14 \pm 10$ \\
\hline Tumor & $9 \pm 3$ & - & $8 \pm 2$ & - \\
\hline
\end{tabular}

Data are presented the mean \pm standard deviation from four mice. ${ }^{a} \mathrm{P}<0.05$ vs. respective value for $\left[{ }^{131} \mathrm{I}\right] \mathrm{I}-\mathrm{G} 3-\mathrm{H}_{6}$. ID, injected dose.

The present study further investigated the biodistribution of $\left[{ }^{125} \mathrm{I}\right] \mathrm{I}-\mathrm{G} 3-\mathrm{H}_{6}$ in SKOV3-bearing BALB/c nu/nu mice when the $\mathrm{Na} / \mathrm{I}$-symporters were blocked by cold $\mathrm{KI}$. The uptake of $\left[{ }^{125} \mathrm{I}\right]$ I-G3- $\mathrm{H}_{6}$ in the tumor and kidneys was at the same level as the uptake of $\left[{ }^{131} \mathrm{I}\right] \mathrm{I}-\mathrm{G} 3-\mathrm{H}_{6}(\mathrm{P}>0.05$; unpaired t-test). The blocking of $\mathrm{Na} / \mathrm{I}$-symporters resulted in a marked decrease in uptake in the salivary glands and stomach. There was a significant $(\mathrm{P}<0.05$; unpaired t-test) improvement of tumor-to-organ ratios for every organ, except the kidneys and bone (Table IV).

Specificity of HER2 targeting by radioiodinated DARPins was confirmed in BALB/C nu/nu mice bearing A431 xenografts with a low level of HER2 expression (Fig. 6). The tumor uptake of [ $\left.{ }^{125} \mathrm{I}\right] \mathrm{I}-\mathrm{HPEM}-\mathrm{G} 3-\mathrm{GGGC}$ and $\left[{ }^{131} \mathrm{I}\right] \mathrm{I}-\mathrm{G} 3-\mathrm{H}_{6}$ was significantly $(\mathrm{P}=0.007$ and $\mathrm{P}=0.005$, respectively; unpaired t-test) lower in A431 xenografts compared with SKOV3 xenografts.

Data from the ex vivo measurements were confirmed by experimental imaging (Figs. 7-9). The SPECT/CT data revealed a high activity accumulation in SKOV-3 xenografts with already-high HER2 expression at $1 \mathrm{~h}$ following injection (Fig. 7A). Besides the tumor, appreciable activity accumulation was visualized in the kidneys and stomach. Activity uptake in other tissues was lower compared with that in the tumor at this time point. At the later time points, $2 \mathrm{~h}$ after injection (Fig. 7B) and $4 \mathrm{~h}$ after injection (Fig. 7C), the high activity uptake in the tumor remained, but the activity in the kidneys was considerably reduced. The activity in other normal tissues was also reduced, which resulted in a noticeable increase in the imaging contrast. The activity in the stomach remained high during the whole imaging experiment. Subsequent to imaging, the gastrointestinal tract was excised, and the activity was measured. The highest activity accumulation was observed in the stomach contents (data not shown). The uptake in the A431 xenografts with low HER2 expression (Fig. 8B) was lower compared with that in the SKOV3 xenograft, as expected (Fig. 8A), while the uptake in other tissues followed the same pattern as in the mouse with the SKOV3 xenograft.

To demonstrate the feasibility of PET imaging of HER2-expressing xenografts using the best-performing variant, $\mathrm{G} 3-\mathrm{H}_{6}$ was labeled with the positron emitter iodine-124. MicroPET imaging with $\left[{ }^{124} \mathrm{I}\right] \mathrm{I}-\mathrm{G} 3-\mathrm{H}_{6}$, clearly visualized the HER2-expressing SKOV-3 xenograft at $4 \mathrm{~h}$ pi (Fig. 9). Low accumulation of activity was observed in other organs, with the exception of the stomach contents in the upper abdomen.

\section{Discussion}

In the present study, direct and indirect labeling methods for the radioiodination of DARPin G3 were compared in order to select an imaging probe with the best biodistribution and tumor targeting properties.

Direct radioiodination of proteins using chloramine- $\mathrm{T}$ is a straightforward, fast and robust labeling method that provides high radiochemical yields and high specific activities. However, the number of labels and their position in the protein is not controlled. Indirect radioiodination using bifunctional linkers allows for site-specific attachment of labels and provides well-defined conjugates. The selection of linkers allows for the optimization of biodistribution properties, including intracellular retention and excretion of radiocatabolites. Additionally, the accumulation of radiocatabolites in organs with expression of Na/I-symporters (thyroid, salivary glands and stomach) is generally reduced with indirect iodination $(27,28)$.

The bifunctional HPEM linker bearing an activated phenolic ring and a maleimide group is suitable for 'one-pot' radiohalogenation and conjugation to reactive thiol groups on proteins. The authors of the present study have previously demonstrated that site-specific radiobromination of affibody molecules using HPEM reduces their retention in the kidneys more than 7-fold in comparison with another linker, $\mathrm{N}$-succinimidyl 4-bromobenzoate (38). In a different study, the use of a $\left[{ }^{125} \mathrm{I}\right] \mathrm{I}-\mathrm{HPEM}$ label was even more favorable for decreasing the renal radioactivity of another engineered scaffold protein, ADAPT (39). This attractive feature of HPEM led to its evaluation for site-specific radioiodination of DARPin G3, with the goal of improving the excretion and clearance of radioiodine catabolites in vivo. 
The two labeling approaches used in the present study provided radiolabeled G3 variants with reasonably high radiochemical yields and satisfactory radiochemical purities. The stability of the label was high following direct and indirect labeling.

A HER2-binding saturation assay demonstrated the binding specificity of the two radiolabeled DARPins $\left[{ }^{125} \mathrm{I}\right]$ I-HPEM-G3-GGGC and [ $\left.{ }^{125} \mathrm{I}\right] \mathrm{I}-\mathrm{G} 3-\mathrm{H}_{6}$ to HER2-expressing cells. Cell-bound activity was proportional to the HER2 expression level in the studied cell lines for the two conjugates. Each variant had an equally high affinity to HER2-expressing cells in vitro. These results demonstrated that the indirect labeling method did not alter the binding specificity and affinity of G3-GGGC to HER2.

For the two labeled variants, the pattern of cellular processing was similar and characteristic for a non-residualizing label. Proteins labeled with non-residualizing labels produce lipophilic radiocatabolites that diffuse from cells following internalization and intracellular degradation (40). Following maximal accumulation, the decrease in cell-associated activity was due to the release of radiocatabolites from cells. High cell-associated activity up to $8 \mathrm{~h}$ post-addition indicated the relevance of using these variants for clinical imaging.

HER2-mediated tumor targeting was confirmed for the two radiolabeled DARPins in mice bearing xenografts with different levels of HER2 expression. A significantly lower uptake of DARPins was observed in A431 xenografts (low HER 2 expression) in comparison with SKOV3 xenografts (high HER2 expression).

Comparative biodistribution studies in mice bearing SKOV3 xenografts demonstrated the high accumulation of $\left[{ }^{125}\right.$ I]I-HPEM-G3-GGGC in the intestines, which suggests rapid hepatobiliary clearance of the conjugate. Despite the similar size and affinity of the two G3 variants to HER2, $\left[{ }^{125} \mathrm{I}\right] \mathrm{I}-\mathrm{HPEM}-\mathrm{G} 3-\mathrm{GGGC}$ demonstrated 2-fold lower accumulation in tumors compared with $\left[{ }^{131} \mathrm{I}\right] \mathrm{I}-\mathrm{G} 3-\mathrm{H}_{6}$. These results suggested that $\left.{ }^{[25} \mathrm{I}\right] \mathrm{I}-\mathrm{HPEM}-\mathrm{G} 3-\mathrm{GGGC}$ was quickly removed from the blood circulation via sequestration in the liver. This, in turn, likely led to low bioavailability and less of the conjugate being delivered to the tumor.

An increased liver uptake has previously been observed for the radiobrominated HPEM-affibody conjugate in comparison with an $\mathrm{N}$-succinimidyl 4-bromobenzoate affibody; however, the overall level of uptake was quite low $(1.32 \pm 0.31$ vs. $0.22 \pm 0.03 \% \mathrm{IA} / \mathrm{g}$, respectively) (38). In the case of ADAPT, the C-terminal placement of $\left[{ }^{125} \mathrm{I}\right] \mathrm{I}$-HPEM provided a better tumor uptake compared with $\mathrm{N}$-terminal placement, although it also led to higher liver retention (1.6 \pm 0.8 vs. $0.6 \pm 0.3 \% \mathrm{IA} / \mathrm{g}$ at $4 \mathrm{~h} \mathrm{pi}$, respectively) (39).

Peptide-based chelators containing three glycines GGG at the $\mathrm{C}$ terminus of affibody molecules labeled with technetium-99m (41) and rhenium-188 (42) provide non-residualizing labels with high tumor uptake and low retention in normal organs. On the other hand, the N-terminal placement of GGG in the affibody molecule labeled with technetium- $99 \mathrm{~m}$ results in a high level of hepatobiliary excretion (43). It was therefore hypothesized that the C-terminal placement of GGG in DARPin G3-GGGC would provide low retention of activity in excretory organs and organs with expression of sodium-iodide symporters. The uptake of activity in the salivary glands and stomach was indeed lower for [ $\left.{ }^{125} \mathrm{I}\right] \mathrm{I}-\mathrm{HPEM}-\mathrm{G} 3-\mathrm{GGGC}$ compared with $\left[{ }^{125} \mathrm{I}\right] \mathrm{I}-\mathrm{G} 3-\mathrm{H}_{6}$. However, it is possible that the combination of the GGG amino acid sequence and the HPEM linker at the C terminus of G3 led to increased local hydrophobicity of the conjugate and the primarily hepatobiliary excretion of the labeled protein.

The use of direct radioiodination for labeling of G3- $\mathrm{H}_{6}$ provided significantly higher tumor-to-blood and tumor-to-organ ratios for the lungs and liver, which are important metastatic sites, compared with indirect labeling. The re-uptake of radiocatabolites in the salivary glands, thyroid and stomach was blocked to a large extent by cold iodide, as demonstrated by microSPECT/CT imaging using $\left[{ }^{125} \mathrm{I}\right] \mathrm{I}-\mathrm{G} 3-\mathrm{H}_{6}$ and by microPET/CT imaging using $\left[{ }^{124} \mathrm{I}\right]$ I-G3- $\mathrm{H}_{6}$. Blocking of Na/I-symporters further improved the tumor-to-organ ratios for $\mathrm{G} 3-\mathrm{H}_{6}$. Notably, the blocking of the $\mathrm{Na} / \mathrm{I}$-symporter in the stomach was not complete at the doses of KI used in the present study. It was previously demonstrated in rats that the administration of 'cold' iodide suppressed the accumulation of ${ }^{131} \mathrm{I}$ in the thyroid, but not in the gastric juices, which suggested a lower affinity of gastric symporters to iodide compared with those of the thyroid (44). $\mathrm{G} 3-\mathrm{H}_{6}$ labeled with iodine-124 provided high-contrast PET images of HER2 expression in human xenografts in mice shortly following injection. Direct radioiodination of DARPin G3- $\mathrm{H}_{6}$ is a straightforward and well-established method applicable to a number of radioiodine isotopes, including ${ }^{123} \mathrm{I}$ and ${ }^{124} \mathrm{I}$. Iodine-123 has a half-life of $13.2 \mathrm{~h}$ and emits $159 \mathrm{keV}(84 \%)$ $\gamma$ rays. This emission energy is ideal for modern $\gamma$ cameras and allows for the use of low energy high resolution collimators. Iodine-124 is a positron emitter that offers quantitative PET imaging with high spatial resolution for improved diagnostic accuracy of cancer.

In conclusion, direct and indirect site-specific methods provided stable labeling of DARPins with preserved capacity for binding HER2 in vitro and in vivo. However, an appreciable level of hepatobiliary excretion of [ $\left.{ }^{125} \mathrm{I}\right] \mathrm{I}-\mathrm{HPEM}-\mathrm{G} 3-\mathrm{GGGC}$ was observed in vivo, which hampered efficient tumor targeting. The use of direct radioiodination is therefore the preferred approach for labeling DARPin $\mathrm{G} 3-\mathrm{H}_{6}$ with iodine-123 and iodine-124 for further clinical SPECT and PET imaging of HER2 expression.

\section{Acknowledgements}

The authors would like to thank Mr. Joshua Gentry for proof-reading the paper.

\section{Funding}

The present study was financially supported by grants from the Swedish Cancer Society (grant nos. CAN 2015/350 and 2017/425), the Swedish Research Council (grant nos. 2015-02353 and 2015-02509), the Swedish Agency for Innovation VINNOVA (grant no. 2016-04060), RFBR grant nos. 17-00-00121 (komfi), 18-04-00365 A and 18-34-00899 mol_a for the protein engineering and purification, the State Contract of Russian Federation no. 14.N08.11.0163, and by Tomsk Polytechnic University CE Program. 


\section{Availability of data and materials}

The datasets used and/or analyzed during the current study are available from the corresponding author on reasonable request.

\section{Authors' contributions}

AV participated in the study design, conjugation and labeling chemistry development, in vitro and in vivo studies, data treatment and interpretation, and drafting of the first version of the manuscript. AS and EK performed the production and purification of proteins. RG and JL performed the biochemical and biophysical characterization of proteins. $\mathrm{BM}, \mathrm{JG}, \mathrm{SR}$ and $\mathrm{AO}$ participated in planning and performing in vivo experiments, including imaging, data treatment and interpretation. SD participated in the molecular design of the probes, and supervised the production and purification of proteins, the biochemical and biophysical characterization, and coordinated the project. VT participated in the study design, labeling chemistry development, in vivo studies, data treatment and interpretation, and coordinating of the work at the Uppsala site. All co-authors revised the manuscript and approved the final version.

\section{Ethics approval and consent to participate}

The animal experiments were planned and performed in accordance with Swedish national legislation on laboratory animal protection and were approved by the local Ethics Committee for Animal Research in Uppsala, Sweden.

\section{Patient consent for publication}

Not applicable.

\section{Competing interests}

The authors declare that they have no competing interests.

\section{References}

1. Giordano SH, Temin S, Kirshner JJ, Chandarlapaty S, Crews JR, Davidson NE, Esteva FJ, Gonzalez-Angulo AM, Krop I, Levinson J, et al; American Society of Clinical Oncology: Systemic therapy for patients with advanced human epidermal growth factor receptor 2-positive breast cancer: American Society of Clinical Oncology clinical practice guideline. J Clin Oncol 32: 2078-2099, 2014

2. Van Cutsem E, Bang YJ, Feng-Yi F, Xu JM, Lee KW, Jiao SC, Chong JL, López-Sanchez RI, Price T, Gladkov O, et al: HER2 screening data from ToGA: Targeting HER2 in gastric and gastroesophageal junction cancer. Gastric Cancer 18: 476-484, 2015.

3. Bang YJ, Van Cutsem E, Feyereislova A, Chung HC, Shen L, Sawaki A, Lordick F, Ohtsu A, Omuro Y, Satoh T, et al; ToGA Trial Investigators: Trastuzumab in combination with chemotherapy versus chemotherapy alone for treatment of HER2-positive advanced gastric or gastro-oesophageal junction cancer (ToGA): A phase 3, open-label, randomised controlled trial. Lancet 376: 687-697, 2010.

4. Gianni L, Pienkowski T, Im YH, Roman L, Tseng LM, Liu MC, Lluch A, Staroslawska E, de la Haba-Rodriguez J, Im SA, et al: Efficacy and safety of neoadjuvant pertuzumab and trastuzumab in women with locally advanced, inflammatory, or early HER2-positive breast cancer (NeoSphere): A randomised multicentre, open-label, phase 2 trial. Lancet Oncol 13: 25-32, 2012.
5. de Azambuja E, Holmes AP, Piccart-Gebhart M, Holmes E, Di Cosimo S, Swaby RF, Untch M, Jackisch C, Lang I, Smith I, et al: Lapatinib with trastuzumab for HER2-positive early breast cancer (NeoALTTO): Survival outcomes of a randomised, open-label, multicentre, phase 3 trial and their association with pathological complete response. Lancet Oncol 15: 1137-1146, 2014.

6. Slamon DJ, Clark GM, Wong SG, Levin WJ, Ullrich A and McGuire WL: Human breast cancer: Correlation of relapse and survival with amplification of the HER-2/neu oncogene. Science 235: 177-182, 1987.

7. Wolff AC, Hammond ME, Hicks DG, Dowsett M, McShane LM, Allison KH, Allred DC, Bartlett JM, Bilous M, Fitzgibbons P, et al; American Society of Clinical Oncology; College of American Pathologists: Recommendations for human epidermal growth factor receptor 2 testing in breast cancer: American Society of Clinical Oncology/College of American Pathologists clinical practice guideline update. J Clin Oncol 31: 3997-4013, 2013.

8. Foukakis T, Åström G, Lindström L, Hatschek T and Bergh J: When to order a biopsy to characterise a metastatic relapse in breast cancer. Ann Oncol 23 (Suppl 10): x349-x353, 2012.

9. Houssami N, Macaskill P, Balleine RL, Bilous M and Pegram MD: HER2 discordance between primary breast cancer and its paired metastasis: Tumor biology or test artefact? Insights through meta-analysis. Breast Cancer Res Treat 129: 659-674, 2011.

10. Wilking U, Karlsson E, Skoog L, Hatschek T, Lidbrink E, Elmberger G, Johansson H, Lindström L and Bergh J: HER2 status in a population-derived breast cancer cohort: Discordances during tumor progression. Breast Cancer Res Treat 125: 553-561, 2011.

11. Krasniqi A, D'Huyvetter M, Devoogdt N, Frejd FY, Sörensen J, Orlova A, Keyaerts M and Tolmachev V: Same-day imaging using small proteins: Clinical experience and translational prospects in oncology. J Nucl Med 59: 885-891, 2018.

12. Orlova A, Magnusson M, Eriksson TL, Nilsson M, Larsson B, Höidén-Guthenberg I, Widström C, Carlsson J, Tolmachev V, Ståhl S, et al: Tumor imaging using a picomolar affinity HER2 binding affibody molecule. Cancer Res 66: 4339-4348, 2006.

13. Garousi J, Lindbo S, Nilvebrant J, Åstrand M, Buijs J, Sandström M, Honarvar H, Orlova A, Tolmachev V and Hober S: ADAPT, a novel scaffold protein-based probe for radionuclide imaging of molecular targets that are expressed in disseminated cancers. Cancer Res 75: 4364-4371, 2015.

14. Hackel BJ, Kimura RH and Gambhir SS: Use of (64)Cu-labeled fibronectin domain with EGFR-overexpressing tumor xenograft: Molecular imaging. Radiology 263: 179-188, 2012.

15. Jiang L, Tu Y, Kimura RH, Habte F, Chen H, Cheng K, Shi H, Gambhir SS and Cheng Z: 64Cu-labeled divalent cystine knot peptide for imaging carotid atherosclerotic Plaques. J Nucl Med 56: 939-944, 2015.

16. Terwisscha van Scheltinga AG, Lub-de Hooge MN, Hinner MJ, Verheijen RB, Allersdorfer A, Hülsmeyer M, Nagengast WB, Schröder CP, Kosterink JG, de Vries EG, et al: In vivo visualization of MET tumor expression and anticalin biodistribution with the MET-specific anticalin 89Zr-PRS-110 PET tracer. J Nucl Med 55: 665-671, 2014.

17. Sörensen J, Velikyan I, Sandberg D, Wennborg A, Feldwisch J, Tolmachev V, Orlova A, Sandström M, Lubberink M, Olofsson $\mathrm{H}$, et al: Measuring HER2-receptor expression in metastatic breast cancer using [68Ga]ABY-025 Affibody PET/ CT. Theranostics 6: 262-271, 2016.

18. Binz HK, Stumpp MT, Forrer P, Amstutz P and Plückthun A: Designing repeat proteins: Well-expressed, soluble and stable proteins from combinatorial libraries of consensus ankyrin repeat proteins. J Mol Biol 332: 489-503, 2003.

19. The European Union Clinical Trials Register [Internet]. EudraCT Number 2011-002526-43. Single and Repeat Dose Study of the Safety and Efficacy of AGN-150998 in Patients with Exudative Age-related Macular Degeneration. https://www.clinicaltrialsregister.eu/ctr-search/search?query $=2011-002526-43$. Accessed January 30, 2012.

20. Zahnd C, Kawe M, Stumpp MT, de Pasquale C, Tamaskovic R, Nagy-Davidescu G, Dreier B, Schibli R, Binz HK, Waibel R, et al: Efficient tumor targeting with high-affinity designed ankyrin repeat proteins: Effects of affinity and molecular size. Cancer Res 70: 1595-1605, 2010.

21. Raguin O, Leblanc L, Collin B, Oudot A, Mirjolet JF, Fiedler U and Dolado I: Biodistribution and antitumor efficacy study of novel Her2 targeting DARPins. Cancer Res 74 (Suppl 19): Abstract 5442, 2014 
22. Fiedler U, Metz C, Zitt C, Bessey R, Béhé M, Blanc A, Schibli R, Dolado I, Herbst J, Dawson KM and Kiemle-Kallee J: Pre-clinical antitumor activity, tumor localization, and pharmacokinetics of MP0274, an apoptosis inducing, biparatopic HER2-targeting DARPin. Cancer Res 77 (Suppl 4): Abstract P4-21-18, 2017.

23. ClinicalTrials.gov: [Internet]. Bethesda (MD): National Library of Medicine (US). Identifier NCT03084926. First-in-human Study to Investigate Safety, Blood Levels and Activity of MP0274 in Cancer Patients With HER2-positive Solid Tumors. Accessed December 18, 2018. https://clinicaltrials.gov/ct2/show/ NCT03084926.

24. Goldstein R, Sosabowski J, Livanos M, Leyton J, Vigor K, Bhavsar G, Nagy-Davidescu G, Rashid M, Miranda E, Yeung J, et al: Development of the designed ankyrin repeat protein (DARPin) G3 for HER2 molecular imaging. Eur J Nucl Med Mol Imaging 42: 288-301, 2015.

25. Vorobyeva A, Bragina O, Altai M, Mitran B, Orlova A, Shulga A, Proshkina G, Chernov V, Tolmachev V and Deyev S: Comparative evaluation of radioiodine and technetium-labeled DARPin 9_29 for radionuclide molecular imaging of HER2 expression in malignant tumors. Contrast Media Mol Imaging2018: 6930425, 2018.

26. Steffen AC, Wikman M, Tolmachev V, Adams GP, Nilsson FY, Ståhl S and Carlsson J: In vitro characterization of a bivalent anti-HER-2 affibody with potential for radionuclide-based diagnostics. Cancer Biother Radiopharm 20: 239-248, 2005.

27. Zalutsky MR and Narula AS: A method for the radiohalogenation of proteins resulting in decreased thyroid uptake of radioiodine. Int J Rad Appl Instrum 38: 1051-1055, 1987.

28. Rea DW, Ultee ME, Belinka BA Jr, Coughlin DJ and Alvarez VL: Site-specifically radioiodinated antibody for targeting tumors. Cancer Res 50 (Suppl 3): 857s-861s, 1990.

29. Malakhov MP, Mattern MR, Malakhova OA, Drinker M, Weeks SD and Butt TR: SUMO fusions and SUMO-specific protease for efficient expression and purification of proteins. J Struct Funct Genomics 5: 75-86, 2004.

30. Heckman KL and Pease LR: Gene splicing and mutagenesis by PCR-driven overlap extension. Nat Protoc 2: 924-932, 2007.

31. Studier FW: Protein production by auto-induction in high density shaking cultures. Protein Expr Purif 41: 207-234, 2005.

32. Tolmachev V, Tran TA, Rosik D, Sjöberg A, Abrahmsén L and Orlova A: Tumor targeting using affibody molecules: Interplay of affinity, target expression level, and binding site composition. J Nucl Med 53: 953-960, 2012.

33. McLarty K, Cornelissen B, Scollard DA, Done SJ, Chun K and Reilly RM: Associations between the uptake of 111In-DTPA-trastuzumab, HER 2 density and response to trastuzumab (Herceptin) in athymic mice bearing subcutaneous human tumour xenografts. Eur J Nucl Med Mol Imaging 36: 81-93, 2009.
34. Malmberg J, Tolmachev V and Orlova A: Imaging agents for in vivo molecular profiling of disseminated prostate cancer: Cellular processing of [(111)In]-labeled CHX-A"DTPA-trastuzumab and anti-HER2 ABY-025 Affibody in prostate cancer cell lines. Exp Ther Med 2: 523-528, 2011

35. Björkelund H, Gedda L, Barta P, Malmqvist M and Andersson K: Gefitinib induces epidermal growth factor receptor dimers which alters the interaction characteristics with 125I-EGF. PLoS One 6: e24739, 2011.

36. Tolmachev V, Orlova A and Andersson K: Methods for radiolabelling of monoclonal antibodies. Methods Mol Biol 1060: 309-330, 2014.

37. Wyszomirska A: Iodine-131 for therapy of thyroid diseases. Physical and biological basis. Nucl Med Rev Cent East Eur 15: 120-123, 2012

38. Mume E, Orlova A, Larsson B, Nilsson A-S, Nilsson FY, Sjöberg S and Tolmachev V: Evaluation of ((4-hydroxyphenyl) ethyl)maleimide for site-specific radiobromination of anti-HER2 affibody. Bioconjug Chem 16: 1547-1555, 2005.

39. Lindbo S, Garousi J, Mitran B, Altai M, Buijs J, Orlova A, Hober S and Tolmachev V: Radionuclide tumor targeting using ADAPT scaffold proteins: Aspects of label positioning and residualizing properties of the label. J Nucl Med 59: 93-99, 2018.

40. Shih LB, Thorpe SR, Griffiths GL, Diril H, Ong GL, Hansen HJ, Goldenberg DM and Mattes MJ: The processing and fate of antibodies and their radiolabels bound to the surface of tumor cells in vitro: A comparison of nine radiolabels. J Nucl Med 35: 899-908, 1994.

41. Wållberg H, Orlova A, Altai M, Hosseinimehr SJ, Widström C, Malmberg J, Ståhl S and Tolmachev V: Molecular design and optimization of $99 \mathrm{mTc}$-labeled recombinant affibody molecules improves their biodistribution and imaging properties. J Nucl Med 52: 461-469, 2011.

42. Altai M, Honarvar H, Wållberg H, Strand J, Varasteh Z, Rosestedt M, Orlova A, Dunås F, Sandström M, Löfblom J, et al: Selection of an optimal cysteine-containing peptide-based chelator for labeling of affibody molecules with (188)Re. Eur J Med Chem 87: 519-528, 2014.

43. Engfeldt T, Orlova A, Tran T, Bruskin A, Widström C, Karlström AE and Tolmachev V: Imaging of HER2-expressing tumours using a synthetic Affibody molecule containing the 99mTc-chelating mercaptoacetyl-glycyl-glycyl-glycyl (MAG3) sequence. Eur J Nucl Med Mol Imaging 34: 722-733, 2007.

44. Halmi NS and Stuelke RG: Comparison of thyroidal and gastric iodide pumps in rats. Endocrinology 64: 103-109, 1959. International (CC BY-NC-ND 4.0) License. 